\title{
A Critical Analysis of the Misuse of an Anti-Dowry Law
}

\author{
Neena Rosey Kahlon ${ }^{1}$ and Jasleen Dua ${ }^{2}$ \\ ${ }^{1 \& 2}$ Assistant Professor in Sociology, Sociology Department \\ ${ }^{1}$ Guru Nanak Dev University, ${ }^{2}$ Khalsa College for Women, Amritsar, Punjab, India \\ E-Mail: Kahlon22feb2009@rediffmail.com,jasleendua166@gmail.com
}

\begin{abstract}
The Anti-dowry law, Section 498A was incorporated in the Dowry Prohibition Act, 1961 to protect the married women from a cruelty, marital violence, and dowry abuse is now becoming a source of blackmailing and harassment of the husband and his relatives. Some educated and empowered women are diverging the path of development to an adverse direction. This particular section is providing an unjustified power in the hands of some women for handling marital disputes which irreparably changes the life of husband and his parents. The present study therefore aims to study the determinant factors that are behind the misuse of section $498 \mathrm{~A}$ of Indian Penal Code for which 190 respondents of the Amritsar district are interviewed by using a descriptive research design. The findings revealed that different factors such as Husband's In-laws extra involvement into their marital life, Respondent wife's authoritative nature, Wife's attitude problem, monetary causes, and respondent's physical disease are some of the reasons that is turning this shield into a weapon.
\end{abstract}

Keywords: Dowry Prohibition Act, 1961, Misuse of dowry laws, Section 498A, Male harassment

\section{INTRODUCTION}

Marriage is sacrament by nature and is believed to have been ordained in heaven. It provides a foundation on which the whole superstructure of a peaceful family is built. Marriage acts as a harbour in the tempest of one's life. It ideally provides love, security, companionship, social acceptability, a stable environment, and an identity to the children. It also provides an opportunity for a personal growth, a division of labour, and a commitment for attaining common goals [1].Husband and wife both play a very crucial role in the development of the family and society. The couple promises to nourish each other, share joys and sorrows of their life together. They can preserve the social structure of society by fulfilling their roles sincerely. The institution of marriage and family had always been completely bounded by the religion and traditions. Some social customs like dowry had always control the structure of these both institutions. Dowry had always remained as an indispensable condition of marriage, especially in India. It just varies in a form, context, and intensity from one region to another and from one culture to another culture. It has countless shapes, forms, and attitudes of acceptance [2].

\section{A. The Phenomena of Dowry}

The term Dowry in an ordinary sense means the property that a bride brings with her at the time of marriage from her parental house to the matrimonial house. It includes gifts and valuable assets for both groom and his parents. These are given by the bride's parents and her kinsmen in the consideration of marriage and passes down from holder to heir. Dowry was originally started as love gifts after the marriages among upper castes. During the medieval period, the ruling class of kshatriyas used to transact lots of property as a dakshina, along with their daughters at the time of their marriage to expand their status. Later other dominant castes of north Indian states started doing the same. In such way, the acceptability of dowry has widened, moving beyond upper castes to other religious and tribal groups. It automatically became a prestigious issue in itself and became a tool for enhancing one's social status or economic worth among others [3].

Dowry originates in Indian society, cutting across the caste, class, and community. It has always considered as a customary and voluntary presentation of gifts to the bride, groom and his family during marriage. It has in fact, commidified the marriage and converted that sacred act into a materialistic exchange. With the course of time it had gone far beyond the practice of a dakshina [4]. The evil system of dowry has become an important source for social mobility and class integration especially in the emerging middle as well as upper classes. But the dissatisfaction of a bridegroom's family with the amount of dowry has contributed to crimes like dowry related abuse, physical torture, suicides, and bride-burning.

Dowry related violence is not only a psychological but a social problem also. It has always been identified as a serious threat to a person's overall well-being as well as on the institution of marriage and family. This kind of violence had always remained hidden behind doors but from few decades, it started getting visible to us due to an emergence of active media, feminist campaigns, and debates. The alarming proportion of dowry harassment cases had stirred the common people, scholars, and women organisation to start some movements against it. Certain social as well as legal concerns had been expressed for women by enacting some laws for them. Thus, on recognising the need for preventive and protective legislation for women, especially with reference to dowry related violence, the Dowry Prohibition Act was emerged in the year of 1961.

\section{B. The concept of Dowry Prohibition Act, 1961}

The Dowry Prohibition Act, 1961 prohibits the payment or an acceptance of a dowry. Under this act, dowry is defined 
as a gift that could be demanded or given as a pre-condition for the marriage. Gifts, that are given without any pre condition are not considered as a dowry and are legal. Asking or giving of a dowry can be punished with an imprisonment of at least up to six months or a fine of up to Rs. 15000 or both. It was passed with an ostensible purpose of curbing the evil of dowry. It was an attempt to deal with the problem separately from other issues pertaining to women. It was enacted for governing the conduct of some unscrupulous people and to prevent the dowry crimes against women. It has been amended twice with two major sections of IPC i.e. section 498A and 304B in the year of 1983 and 1986 [5].

The dowry laws were implemented to protect the genuine victims but now-a-days they are being misused by certain educated and empowered women to fulfil their ulterior motives. Unfortunately, the remedy has become worse than the ailment and left a very bitter trial of disappointment to certain men and their families.

\section{Section 498A and its misuse}

This section was inserted in IPC in 1984 it says; " Whoever, either the husband or the relative of the husband of a woman subjects her to a cruelty shall be punished with an imprisonment for a term which can be extended to three years and shall also be chargeable to fine. According to this section cruelty means:

1. Any wilful conduct which is of a nature that drives the woman to commit suicide or cause any grave injury or danger (either physical or psychological) to her life, limb, or health of the woman.

2. Harassment of the woman with a view to constrain her or any person related to her, to meet any unlawful demand for any property or valuable security or is on an account of failure by her or any person related to her to meet such demand [6].

This law was mainly aimed at curbing dowry harassment. The offence is non-bailable (the accused have to be presented in a court of law to obtain bail), non-compoundable (a complaint once filed cannot be withdrawn; except in the state of Andhra Pradesh) and cognizable (arrests are made without issuing a warrant) on a complaint made to the police officer by the victim or by determined relatives. Offenders are liable for imprisonment as well as a fine or both under this section [6].

Undoubtedly, this section was incorporated to provide a relief to the victim from a dowry harassment, cruelty, and marital abuse but now it is more likely to be misused rather than to be used for the purpose it was meant to implemented. It is becoming a source of blackmailing and harassment of the husband and his relatives by some unscrupulous wives. They are leading the law into a wrong side and using it to harass husband and his parents by getting them tied under section 498A. It is providing an unjustified power to some women for handling marital disputes which irreparably damages the life of husband and his parents.

\section{OBJECTIVE OF THE STUDY}

The paper aims to study the determinant factors that are responsible for the misuse of an anti-dowry law i.e. section 498A of IPC which came under the Dowry Prohibition Act, 1961.

\section{METHODOLOGY}

The primary concern of this present study is to describe the new social evil of misusing an anti-dowry law i.e. section 498A of Dowry Prohibition Act, 1961. It is a descriptive study. The data is collected through schedule having the series of questions pertaining to the research topic which suits to the objectives from 190 respondents of the Amritsar district. For the selection of the sample, the last ten years (From 2003 to 2013) record from the district court has been analysed where the husband and his family members were legally acquitted by the court.

\section{RESULTS}

TABLE I REPORTED REASONS BEHIND THE ABUSE OF SECTION 498A

\begin{tabular}{|c|l|c|c|}
\hline $\begin{array}{c}\text { S. } \\
\text { No. }\end{array}$ & \multicolumn{1}{|c|}{ Reported reasons } & $\begin{array}{c}\text { Number of } \\
\text { Respondents* }\end{array}$ & Percentage \\
\hline 1. & In-Law's interference & 120 & 63.15 \\
\hline 2. & Authoritative nature & 60 & 31.57 \\
\hline 3. & Monetary causes & 20 & 10.52 \\
\hline 4. & Love Affair & 24 & 12.63 \\
\hline 5. & Attitude Problem & 40 & 21.05 \\
\hline 6. & Physical Disease & 03 & 1.57 \\
\hline \multicolumn{4}{|c|}{$\mathrm{N}=190 *$ Multiple Responses } \\
\hline
\end{tabular}

\section{A. Respondent's In-Laws Interference}

Respondent's In-laws play a crucial role in filing a dowry complaint against him and his parents. They do so either to take revenge or for their daughter's wish. In such situation where the parents of a woman should save the marriage of their daughter by resolving their small marital disputes, they add more tensions. Woman got full support of her paternal family to meet the litigation cost which put them forward to register other allegations against her matrimonial family and his relatives also who are not even residing with the victim.

The woman and her parent's objective behind filing a false complaint against section $498 \mathrm{~A}$ are to subject the husband and In-laws to a big distress. The whole situation is designed to pressurize them to accept his wife's demands. This law mainly targets to those families who seem to be vulnerable to legalized extortion by corrupt agencies of government. The data in table I confirms the researcher's observation and reveals that one hundred twenty (63.15 per cent) of respondents alleged their In-laws responsible for such suffering. The following points will also show how the extra involvement of respondent's In-laws in their marital life has ended that marriage. 


\section{B. In-Laws Reaction to their Minor Marital Disputes}

Small marital conflicts between husband and wife are the part of every marriage but when the same matrimonial discord reached a stage where they are unable to resolve it. Then the respondents either preferred to share it with their own parents or In-laws with an expectation for getting any solution for their dispute. But certain woman's parents instead of resolving their dispute, they have adopted a very impartial and negative attitude towards the respondent.

TABLE II REACTION OF IN-LAWS REPORTED BY RESPONDENT

\begin{tabular}{|c|l|c|c|}
\hline S. No. & Type of Reaction & $\begin{array}{c}\text { Number of } \\
\text { Respondents* }\end{array}$ & Percentage \\
\hline 1. & Negative & 126 & 79.75 \\
\hline 2. & Neutral & 28 & 17.72 \\
\hline 3. & Positive & 04 & 2.53 \\
\hline \multicolumn{2}{|r|}{ Total } & 158 & 100.00 \\
\hline
\end{tabular}

Out of the total sample of one ninety respondents, the majority (158) had discussed this issue either with parents or In-laws. These respondents were further requested to state their In-laws response. Table II shows that more than three fourth (79.75 per cent) of the respondents stated that their in-laws simply defended their daughters. They blamed their son-in-law and his parents for the dispute. Twenty eight (17.72 per cent) remained neutral. A negligible proportion of 2.53 per cent respondents reported a positive response from their In-laws. Wife's parents blamed their own daughter for this fuss.

\section{Women's Over-Dependence on Parents}

Through the decades, an ideology had always been followed by the patriarchal culture that girl's actual home is her Inlaws house. It is always considered bad if she visits her parents too frequently or staying there for a long period on the pretext of neglecting her matrimonial home. But with time this ideology has changed. Now she is permitted to visit her parents after her marriage by the majority of the In-laws. It is good for gender equality but some wicked women are taking undue advantage of this liberty.

The over-dependence on parents after marriage can also create obstacles in their adjustment at the matrimonial house. Thus sometimes women's over-dependence on their parents after marriage proves to be one of the main reasons behind the misuse of section 498A.

TABLE III FREQUENCY OF WOMAN'S VISIT TO HER PARENTAL HOUSE

\begin{tabular}{|c|l|c|c|}
\hline $\begin{array}{c}\text { S. } \\
\text { No. }\end{array}$ & $\begin{array}{c}\text { Number of visits(per } \\
\text { month) }\end{array}$ & $\begin{array}{c}\text { Number of } \\
\text { Respondents }\end{array}$ & Percentage \\
\hline 1. & Once in a month & 18 & 9.47 \\
\hline 2. & $2-3$ & 44 & 23.16 \\
\hline 3. & $4-5$ & 83 & 43.69 \\
\hline 4. & More than 5 & 45 & 23.68 \\
\hline & Total & 190 & 100.00 \\
\hline
\end{tabular}

Table III shows that 43.69 per cent respondents stated that their wife visited their parents four to five times a month. Many times she mainly stays there for at least four to five days. 23.68 per cent respondent's wives visit more than five times in a month followed by 23.16 per cent had 2-3 visits to their parental house. Only 9.47 per cent women visit their parent's house once a month. This data reflects that frequent visit to parent's house after marriage could also disturb one's marital life.

\section{Role of Wife's Mother in her Marital Life}

The discord in marriage mainly arises when either the wife refuses to adjust herself in the family or the husband remains reluctant to adjust with his wife. The other thing which can also disturb one's marriage is the unnecessary interference of the woman's parents especially her mother. It is she who can save or destroy the marital life of her daughter. A fact that cannot be denied is where a woman's mother has a dominating nature and plays a role of an instigator in her household, There her daughter would also try to control her In-laws family. But if they resist in fulfilling her demands then she just threatens to file a case of dowry harassment under section 498A of IPC. The interference of a woman's parents and especially of her mother can be analysed through the frequency of a communication with her mother in a day.

The data in table IV clearly reveals that majority of the respondents ( 88.42 per cent) responded that their wife talked to their mother at least once or twice a day. 11.58 per cent stated that she talked three to four times a day with her mother. It clearly shows that where the woman shares each and every regular activity conducted in the matrimonial house with her mother there the marital conflict is common. Some mothers always interfere in their daughter's marital life by advising them certain adverse ideas to use against their husband and In-laws.

TABLE IV FREQUENCY OF COMMUNICATION WITH MOTHER

\begin{tabular}{|c|c|c|c|}
\hline $\begin{array}{c}\text { S. } \\
\text { No. }\end{array}$ & $\begin{array}{c}\text { Frequency of } \\
\text { Communication } \\
\text { (in a day) }\end{array}$ & $\begin{array}{c}\text { Number of } \\
\text { Respondents }\end{array}$ & Percentage \\
\hline 1. & $1-2$ times & 168 & 88.42 \\
\hline 2. & $3-4$ times & 22 & 11.58 \\
\hline & Total & 190 & 100.00 \\
\hline
\end{tabular}

\section{E. Authoritative Nature}

There is a fact that patriarchy is a system of social structures and practices into which men mainly oppress and control women. It was created and sustained through social norms, values, traditions and social segregation of gender roles which infused through the process of long-lasting socialization. Patriarchy has been historically a traditional social system. But recently the discourses on patriarchy are being modified. They are perpetuating new ways in the family through women which are called as 'neo-patriarchy'. This 
new form has occurred through the historical and structural development of the society. Here the power and control are operated by a woman over other family members [7].

In the system of patriarchy, the girls were always trained to be submissive, fragile, obedient, and, good home-makers. This shift from patriarchy to neo-patriarchy has made some women totally contrary to all. They are opting for an attitude of dominance in their matrimonial families. It is done to suppress the husband and In-laws. But somewhere it creates a problem in the marital life. In the misused cases of section 498A also, the authoritative attitude of some women towards their husband and In-laws became one of the reason for a dispute. They wanted to enhance their bargaining position to have a controlling power in their hands of their matrimonial house. They expect from their husband to live separate.

The women also insist their husband to have a house near to her parental house. The cases where the husband despite getting separated from his parents were not ready to tolerate their wife's or her parent's authoritative behaviour. There the wife with the support of her parents charged a case under this section over her husband and In-laws. They made them accused in the eyes of law. In the present study, the data in previous table I depicts that Sixty (31.57 per cent) respondent's wife has misused this section due to their authoritative nature.

\section{F. Monetary Causes}

An economic structure of a country determines its people's attitude. The Industrial revolution has shifted the Indian economy from an agricultural base to the industrial base. It has paved the way for capitalism and modern scientific development which further have made the life of an individual as well as the attitude of society totally materialistic.

But in this era where the societal landscape is changing some women are also adopting a materialistic attitude. They are taking marriage as a source of fulfilling their certain unsatisfied materialistic desires and continuously misusing this particular dowry law as they knew very well that they are protected by the laws. The data mentioned in previous table 1 reveals that out of one ninety respondents, as many as twenty (10.52 per cent) respondents have mentioned that their wives have misused the section for the sake of money. Her parental greed is somewhere responsible for abusing the particular dowry law.

\section{G. Love Affair}

Marriage in India is regarded as a sacred relationship based on the foundation of love, trust, faith, and hope. These are the biggest contributor to any marriage. If these are broken, marriage is likely to break up because it is very difficult to tolerate unfaithfulness in a marital relationship. However, the love affair can spoil a good marital relationship.
The data in Table I show that Twenty four (12.63 percent) respondents stated that their wives love affair has affected their marital relationship and due to disclosure of it they accused their husband and in-laws under section 498A.

\section{H. Attitude Problem}

Marriage is such a type of institution which remains stable on its two major pillars i.e. male and female. Both carry their own personality traits and might be different from one another. But both have some desires and expectations from each other which could be economical, physical or emotional. In the case of dissatisfaction with any of their expectation, a peaceful marriage has to go through a big tempest. The cases where the women were unable to adjust with their husband and In-laws, there they made dowry as a scapegoat to escape from their minor marital problem. The result in the previous table I reveals that forty (21.05 per cent) respondents reported that due to an attitude problem their wife has misused the law against them.

\section{Physical Disease}

Health is simply viewed as an absence of disease. WHO (1948) defined health as a state of complete physical, mental and social well-being and not mainly the absence of diseases or infirmity. The healthy person's body and mind interlock harmoniously in a balanced situation. It is the condition wherein a person is at the peak of enjoyment of physical, mental and emotional experience having regarding the environment, age, sex and other biological characteristics. But health never remains static and it fluctuates within a range. When a bodily health gets seriously deranged than this departure from a state of health is called illness which is more a subjective experience that usually results in an individual's modified behaviour [8].

Table I depicts the result that only Three ( 1.57 per cent) respondents perceived that their ailment was the major reason behind the misuse of this particular section by their wife. They state that due to their illness they were unable to give any support (physical and economical) which every wife expects from her husband. Such a thing has disrupted their marital life and their wife had left them to live their life according to their own wishes. But while seeking divorce they transformed a simple divorce case into a dowry case just to earn some alimony by levelling the charges of bringing less dowry and harassment on him and his parents.

\section{CONCLUSION}

The sole objective of the Dowry Prohibition Act, 1961 and one of its amended Section 498A was to give a legal protection to the married women against victimization by their husband and his family. This anti-dowry law always aimed at safeguarding the interest of women. But these women protective laws have now become a handy weapon for some women to blackmail, harass, and humiliate certain innocent members who include husband and his family. 
The increasing number of false dowry cases is adversely affecting the minds of Indian youth. It is creating a fear into their mind which is resisting them to enter into the institution of marriage [9]. Today time demands an equal law for the men to protect them against the evil shadow of dowry laws. This anti-social abuse of a provision of law is growing into a legal terrorism in the society. The abuse of dowry laws is proving a statement right that the movement of marriage is that important decision of life which can extremely change the life of not only the husband and wife but of the whole family also.

\section{REFERENCES}

[1] Ratra, A. et al.,(2006). Marriage and Family: In Diverse and Changing Scenario, New Delhi: Deep and Deep Publications.
[2] Kumari,Ranjana.(1989). Brides are not for burning: Dowry victims in India, Hyderabad: Radiant Publishers.

[3] Paul, M.C.(1986). Dowry and position of women in India: A study of Delhi Metropolis, New Delhi: Inter-India Publication.

[4] Luthra, Arti. (1983). Dowry among the urban poor, Social Actions, 33(2), 194-217.

[5] Gupta, D.N., \& Singh, C. (2003). Human Rights: Acts, Statutes and constitutional provisions, New Delhi:Kalpaz Publication.

[6] Kusum. (1991). Harassed husbands, New Delhi: Regency publications.

[7] Habiba, U., \& Ali, R. (2016). From Patriarchy to Neo-Patriarchy: Experiences of Women from Pakistan, International Journal of $\mathrm{Hu}$ manities and Social Science, 6(3), 26-39.

[8] Mehta,J.C. (1977). Habitat: Human settlements and environmental health: A systematic approach, New Delhi: New Asia publication.

[9] Singh, R., \& Singh, V. (2008). Socio-Economic offences in India, Haryana: Allahabad Law Agency. 